Article Type: Research Paper

\title{
The Role of Entrepreneur Characteristic and Financial Literacy in Developing Business Success
}

\author{
Mohamad Nur Utomo*, Widyastuti Cahyaningrum, and Kaujan
}

\begin{abstract}
One important contribution of Small-and-Medium Enterprises (or SMEs) to the economic development is the absorption of workers. Absorbing more workers and reducing unemployment are achievable only if SMEs have been success in managing the sustainability of their business. The success of SMEs' business is determined by few variables, which are to be examined in this research. Therefore, research is aimed to conduct empirical test over the effect of entrepreneur characteristic and financial literacy on business performance. Type of data is primary, which is acquired through distribution of questionnaire to respondents. Research sample includes Small-and-Medium Enterprises (SMEs) in Tarakan City. Analysis technique is Partial Least Square-Structural Equation Modelling (PLS-SEM). Result of research showed that personal characteristic, psychological characteristic, entrepreneur competency, and financial literacy are determinants to SMEs' performance. Theoretical implication of this research is that research findings are supporting upper echelon theory and RBV theory when both theories explain factors that determine performance.
\end{abstract}

\section{CITATION:}

Utomo, M. N., Cahyaningrum, W., \& Kaujan. (2020). The Role of Entrepreneur Characteristic and Financial Literacy in Developing Business Success. Jurnal Manajemen Bisnis, 11(1), 26-42.

Received: 25 August 2019

Accepted: 15 January 2020

Keywords: Entrepreneur Competency; Financial Literacy; Business Performance; SMEs; Tarakan City.

\section{Introduction}

It is undeniable that Small-and-Medium Enterprises (or SMEs) always have important roles in economic growth of Indonesia. Its contribution to Gross Domestic Income (GDI) is huge, which reaches around IDR 7,005,950,000 or $62.57 \%$ of Total GDI (LEI, 2018). Besides having position that determines economic growth, SMEs become front runner in alleviating unemployment. Sudarno (2011) found that SMEs in Depok City can absorb 534,500 workers or $73 \%$ of total workforces. Small-and-Medium Enterprises are potentially capable to grow the spirit of entrepreneurship (Sari, Suwarsinah, \& Baga, 2016). One reason is because entrepreneurship is one of indirect methods to alleviate unemployment (Sukidjo, 2005). One incentive behind the development of SMEs' volume is high entrepreneurship motivation.

One determinant of SMEs' success is entrepreneur characteristic. Several studies have shown that entrepreneurship characteristic has positive effect on SMEs' performance (Abdulwahab \& Al-Damen, 2015; Abood \& Aboyasin, 2014; Isaga, 2017; Mothibi, 2015). 


\section{Utomo, Cahyaningrum, \& Kaujan \\ The Role of Entrepreneur Characteristic and Financial Literacy in Developing Business Success}

In general, entrepreneur characteristic is the representation of personal or psychological attributes, which are made of attitude and interest (Sari et al., 2016). To be noted, entrepreneur characteristic is many and varying. The diversity of entrepreneur characteristic, thus, is arranged into three dimensions, namely, personal dimension, entrepreneurial dimension (related with innovation), and managerial/organizational dimension (Abood \& Aboyasin, 2014).

In the other hand, SMEs have weaknesses that can be the factor of failure to the business. Among these factors are low financial literacy, poor access to the bank, bad financial control, and inappropriate investment strategy (Arasti, Zandi, \& Bahmani, 2014). Most SMEs' entrepreneurs do not use the advance financial analysis instruments to manage their business, and thus, they find themself as weak in financial literacy (Plakalovic, 2015). Empirical study conducted by Lusardi and Mitchell (2007) has indicated that not only financial literacy is low either in developing or developed countries, but also only few peoples can understand the basic concept of finance. In 2016, Financial Literacy Index of Indonesia is low, which it can reach around $29.7 \%$. In other words, Indonesian peoples who use financial products and services are $67.8 \%$, but it is only $29.7 \%$ of them who are well financially literate (OJK, 2016).

That business owners or entrepreneurs are required to have financial literacy is a crucial issue in both developing and developed countries due to the change of their financial landscape (Hilgert \& Hogarth, 2003). Several studies already showed that financial literacy can substantiate the opportunity of business success and business sustainability because entrepreneurs are given flexibility to access financial facility (Adomako \& Dans, 2014; Aribawa, 2016; Dahmen \& Rodríguez, 2014). Therefore, the understanding about financial literacy is surely important to SMEs' entrepreneurs when they are determined to develop their business success.

The objective of this research is to elaborate the relationship between entrepreneur characteristic and financial literacy, and to examine the role of both variables on SMEs' success in developing their business. Research takes place at SMEs in Tarakan City. This research location is selected because there is a limited number of researches that examine the effect of entrepreneur characteristic and financial literacy on business performance of Tarakan SMEs. Ariani and Utomo (2017) found that the weaknesses of SMEs in Tarakan City are: 1) Capital limitation; 2) Lack of understanding about business management, and strategy, system, and process of marketing; 3) Not yet enlisted into business association in Tarakan City; 4) Lack of marketing network and supporting information technology; and 5) Lack of availability for human resources with the required skills and experiences. Through these findings, Ariani and Utomo (2017) declared that some of these weaknesses are indicators that explain entrepreneur characteristic, such as low managerial competency, and lack of skills and experiences, while others are indicators that explain financial literacy, such as capital limitation and lack of information technology network. Considering this explanation as background, the current research attempts to understand how is the effect of entrepreneur characteristic and financial literacy on business performance of SMEs in Tarakan City. 


\title{
Literature Review and Hypotheses Development
}

\author{
Entrepreneur Characteristic
}

Entrepreneurship is defined as a process of creating, developing, arranging and managing new enterprise, and then bring it to achieve the success (Abdulwahab \& Al-Damen, 2015). Entrepreneurship is the main pillar in free market economic, and this position has been recognized since proto-capitalist age in the ancient Greek civilization (Karayiannis, 2003). Entrepreneurship plays significant roles in economic development, such as being the backbone of national development, creating employment, and supporting efforts into prosperity (Abdulwahab \& Al-Damen, 2015).

Some studies explained that entrepreneurs have some characteristics. Hornaday (1982) mentioned that entrepreneurs are identified by characteristics such as self-confidence and optimism, risk considerate, positively responding challenge, adaptability, knowledge about market, independent thought, energetic and diligence, need for achievement, dynamic leader, replying the proposal, taking initiative, patience, future vision, and dealing with critics. Chell (2008) added another characteristics such as capable to identify opportunity, self-reliant, self-efficient, social leadership, intuitive, and having future vision.

Abood and Aboyasin (2014) described that entrepreneurs can be identified through three (3) characteristics, respectively: 1) Personality, explained by indicators of sense of capability and diligence, self-reliant, personal enthusiasm, self-confident anhd optimism, courageous and responsible, and highly motivated toward achievement; 2) Innovative, measured by indicators of having future vision as the motivation of current act, risk taking, thinking out of the box, capable to capture opportunity, being flexible, and thinking openly; 3 ) Managerial and Organizational Competencies, which is described by indicators of managerial and organizational experiences, dislike the routines (orr traditions), sense of authority and control on what is doing (internal control), capable to invest the resources at proper place, efficient self-management, and social competency (building relationship with others).

Sari et al. (2016) divided entrepreneur characteristic into three (3) variables, respectively :1) Personal (Individual) Characteristic, which is explained by indicators of age, education, experience (related with entrepreneurship) and cosmopolite; 2) Psychological Characteristic, which is measured by indicators of hard working, self-confident, discipline, dare to take the risk, tolerance to uncertainty, innovative, self-reliant, and responsible; and 3) Entrepreneurship Competency, which is decribed by indicators of managerial competency, conceptual competency, social competency, decision-making competency, and timing competency.

\section{Financial Literacy}

Entrepreneurs must face a reality that they make various complex financial decisions to improve their business. For example, entrepreneurs must make financial decisions in the 


\section{Utomo, Cahyaningrum, \& Kaujan \\ The Role of Entrepreneur Characteristic and Financial Literacy in Developing Business Success}

form of savings, investments, and pensions. Financial literacy, therefore, is very important feature to entrepreneurs' financing decisions, which then affects their performance (Adomako \& Dans, 2014).

Financial literacy is the understanding and knowledge about financial principles that must be used in the making of financial decisions and products in order to give an impact of improving welfare (Basu, 2005). Financial literacy is also a discipline of personal financial facts and a key for personal financial management (Garman \& Forgue, 2002).

Entrepreneurs' understanding and knowledge about finance (or financial literacy) can be estimated through indicators. Dahmen and Rodríguez (2014) assess financial literacy of SMEs' entrepreneurs through four (4) indicators, respectively: (i) the preparation of monthly financial statement (earning/loss statement and balance sheet); (ii) the review on monthly financial statement; (iii) the financial analysis over monthly financial statement; and (iv) the understanding about gross earning ratio and its contribution to total earnings. These indicators are arranged in Likert Scale at 7 points starting from very agree to very disagree. Chen and Volpe (1998) assess financial literacy level also with four (4) indicators, which include basic knowledge about how to manage finance, credit, savings \& investment, and risk. Aribawa (2016) estimates financial literacy level through some indicators, such as: 1) Opening bank account on behalf of enterprise; 2) Enterprise identification during account opening; 3 ) Minimum fund deposit during account opening; 4) Knowledge about surety of savings; 5) Understandings about potential returns of savings in a year; 6) Understandings about potential returns of savings in multi-years; 7) Understandings about annual credit interest; 8) Knowledge about premium of two optional products; 9) Knowledge about the effect of inflation on currency; 10) Knowledge about value of money over times; and 11) Understandings about the effect of inflation on firm growth.

\section{Performance of Small-and-Medium Enterprises}

Small-and-Medium Enterprises (SMEs) are said to be successfully managed if they have good performance. Their performance is affected by many factors, either in positive or negative ways. Mostly, the success comes from how entrepreneurs think about how they should plan their business strategy (Singh \& Pathak, 2013). Entrepreneurs' behavior can give a distinguishing effect on business performance (Davis, Marino, \& Vecchiarini, 2013). Entrepreneurs always play significant role in the success and sustainability of business.

The performance of SMEs can be measured with indicators. Adomako and Dans (2014) used indicators, such as: Return on Asset (ROA), Return on Equity (ROE) and Tobin's Q market value to assess SMEs' performance . Aribawa (2016) measured SMEs' performance with several indicators, such as: job is done on plan and schedule; job mistakes are too often and causing repetition; the sale is growing; fixed cost is declining; anticipation of production on demand is improving; and there is a surety of punctuality for customers and for compatibility of product and specification. Sari et al. (2016) defined business performance through indicators of earnings and sale. 
Upper Echelon Theory believes that there is relationship between entrepreneur characteristic and business performance. This theory also says that organization and anything inside it are the reflection of top-management's characteristic (Hambrick \& Mason, 1984). Entrepreneur characteristic intended by this research is the observable characteristic, such as age, term, functional path, career experience, formal education, heterogenity, managerial process, and organizational performance (Sambu \& Kihara, 2015).

Some empirical reviews explain that entrepreneur characteristic is affecting business performance. Abdulwahab and Al-Damen (2015) examined the impact of entrepreneur characteristic on business success by observing Jordanian small enterprises that have business in medical equipments and devices. They found that entrepreneur characteristic has positive effect on the success of these enterprises. By this finding, it can also be said that the success of small business is closely related with entrepreneur characteristic.

Mothibi (2015) conducted an empirical study to analyze the effect of entrepreneur characteristic on business performance at Small-and-Medium Enterprises (SMEs) in Pretoria. Structured questionnaire is used to collect the data about the characteristics of entrepreneurs and enterprises, which are perceived as affecting performance of the enterprises. Based on the result of multiple regression analysis, it is found that managerial competency, education qualification, work experience, location, firm size, business duration, and business sector, have significant and positive effect on SMEs' performance. Isaga (2017) has studied three hundreds (300) Small-and-Medium Enterprises (SMEs) at furniture sector in four different regions of Tanzania. Structural Equation Modelling (SEM) is used as the approach to the simultaneous tests over direct and indirect effects of entrepreneur characteristic on SMEs' performance. The finding shows that personal characteristic of entrepreneurs, represented by cognitive characteristic, has significant effect on SMEs' performance.

Given the explanations previously given, then three (3) hypotheses are made. The third hypotheses are written as follows:

\section{$\boldsymbol{H}_{1}$ : Personal Characteristic has positive effect on Business Performance. \\ $\boldsymbol{H}_{\mathbf{2}}$ : Psychological Characteristic has positive effect on Business Performance. \\ $H_{3}$ : Entrepreneur Competency has positive effect on Business Performance.}

The Effect of Financial Literacy on Business Performance

Causal relationship between financial literacy and business performance is emphasized by Resource-Based View (RBV) Theory. This theory explains that if enterprises have capability to manage the resources into valuable, rare, inimitable and unsubstitutable products, 
these enterprises should have high performance, better growth, and sustainable competitive advantage (Barney, 1991). High financial literacy helps enterprises to access financial sources (as resources) in order to be optimally used to create firm value (Adomako \& Dans, 2014).

The positive effect of financial literacy is already stressed by several empirical reviews. Dahmen and Rodríguez (2014) in their empirical study have found a strong relationship between financial literacy and financial performance of the firms. Based on their survey on small entrepreneurs in United States, it is found that $50 \%$ business owners (7/14) do not regularly monitor their financial statement and as a consequence, they find most of their business $(86 \%$, or $6 / 7)$ suffering from financial difficulty. It can be said that poor financial literacy causes entrepreneurs to suffer from financial trouble.

Aribawa (2016) confirmed that financial literacy affects business performance and business sustainability of Small-and-Medium Enterprises at creative sector in Central Java. It has implication that by having good financial literacy, thus, SMEs must be able to make proper decisions on managerial and financial issues to ensure the improvement of business performance and business sustainability.

Eniola and Entebang (2016) reviewed the effect of financial literacy on performance of Small-and-Medium Enterprises in Nigeria. Result of this review confirmed that the knowledge about finance should help entrepreneurs to get better business performance. This result clarifies the importance of financial literacy for all SMEs owners when they manage their business.

Taking into account all studies above, a hypothesis is developed:

$\boldsymbol{H}_{4} \quad$ : Financial Literacy has positive effect on Business Performance.

\section{Research Method}

Research Variable and Research Indicator

There are five (5) latent variables observed and measured by this research, and these include personal characteristic, psychological characteristic, entrepreneur characteristic, entrepreneur competency and financial literacy. These four variables are independent/exogenous variables, while business performance is dependent/endogenous variable.

All these variables are latent/unobserved (unmeasured) variables, and these are proxied by using perception of respondents on predetermined indicators. Variables and indicators of this research are described in the following Table 1. 
Table 1 Variables and Indicators of Research

\begin{tabular}{|c|c|c|c|}
\hline No & Latent Variable & Indicator of Variable & Reference \\
\hline 1. & $\begin{array}{l}\text { Personal } \\
\text { Characteristic } \\
\text { (Exogenous } \\
\text { Latent) }\end{array}$ & $\begin{array}{ll}\text { 1. } & \text { Age } \\
\text { 2. Education } \\
\text { 3. Experience } \\
\text { 4. Cosmopolite }\end{array}$ & (Sari et al., 2016) \\
\hline 2. & $\begin{array}{l}\text { Psychological } \\
\text { Characteristic } \\
\text { (Exogenous } \\
\text { Latent) }\end{array}$ & $\begin{array}{l}\text { 1. Hard working } \\
\text { 2. Self-confident } \\
\text { 3. Discipline } \\
\text { 4. Dare to take the risk } \\
\text { 5. Innovative } \\
\text { 6. Self-reliant and responsible } \\
\text { 7. Having future vision } \\
\text { 8. Thinking out of the box } \\
\text { 9. Capable to capture opportunity } \\
\text { 10. Flexible and open-minded }\end{array}$ & $\begin{array}{l}\text { (Abood \& } \\
\text { Aboyasin, 2014; } \\
\text { Sari et al., 2016) }\end{array}$ \\
\hline 3. & $\begin{array}{l}\text { Entrepreneur } \\
\text { Competency } \\
\text { (Exogenous } \\
\text { Latent) }\end{array}$ & $\begin{array}{l}\text { 1. Managerial competency } \\
\text { 2. Conceptual competency } \\
\text { 3. Capable of making decisions } \\
\text { 4. Capable of setting times } \\
\text { 5. Managerial and organizational } \\
\text { 6. Dislike the routines (or traditions) } \\
\text { 7. Internal control } \\
\text { 8. Capable to invest resources } \\
\text { 9. Efficient self-management } \\
\text { 10. Social competency }\end{array}$ & $\begin{array}{l}\text { (Abood \& } \\
\text { Aboyasin, 2014; } \\
\text { Sari et al., 2016) }\end{array}$ \\
\hline 4. & $\begin{array}{l}\text { Financial } \\
\text { Literacy } \\
\text { (Exogenous } \\
\text { Latent) }\end{array}$ & $\begin{array}{l}\text { Knowledge about: } \\
\text { 1. Financial management } \\
\text { 2. Credit management } \\
\text { 3. Savings \& investment management } \\
\text { 4. Risk management }\end{array}$ & $\begin{array}{l}\text { Chen and Volpe } \\
\text { (1998) }\end{array}$ \\
\hline 5. & $\begin{array}{l}\text { Business } \\
\text { Performance } \\
\text { (Endogenous } \\
\text { Latent) }\end{array}$ & $\begin{array}{l}\text { 1. Earnings } \\
\text { 2. Sale rate } \\
\text { 3. Fixed cost lowering } \\
\text { 4. Be anticipative in production on } \\
\text { the increasing demand } \\
\text { 5. Surety of punctuality for customers }\end{array}$ & $\begin{array}{l}\text { (Aribawa, 2016; } \\
\text { Sari et al., 2016) }\end{array}$ \\
\hline
\end{tabular}

Source: Empirical theories and studies that are relevant to this research.

Population and Sample of Research

Population of this research includes all Small-and-Medium Enterprises (SMEs) in Tarakan City. Sampling technique is area probability sampling. By this technique, sample where data are collected is determined based on area. The area intended by this research includes several districts, such as Central Tarakan, West Tarakan, East Tarakan and North Tarakan. The sample is obtained by subjecting research population to the criteria of financial literacy, which include has savings in public banks, and has ever received business credit from banking and non-banking financial institutions. One hundred (100) respondents constitute the sample and each comes from different background of 
business, such as trade, service, or home industry. The sample of this research is entrepreneurs of Small-and-Medium Enterprises (SMEs), who are perceived as such based on definition given by Law No.20/2008 and Central Bureau of Statistics.

Data collection technique involves the compilation of primary data. Field study is conducted at research location and questionnaires are distributed to respondents (SMEs' entrepreneurs). The answers to questionnaires provide the needed data, and then data are differentiated into time dimensions. Therefore, data of this research are cross sectional.

\section{Analysis Model}

Research hypotheses are tested using the combination of Partial Least Squares (PLS) and Structural Equation Modelling (SEM), which is operated with WarpPLS version 6.0. Research model that the author wants to elaborate is written as follows:

$P=\alpha+\beta 1 P e r C+\beta 2 P s y C+\beta 3 E C+\beta 4 F L \alpha+e$

where $\mathrm{P}=$ Business Performance, PerC $=$ Personal Characteristic, $\mathrm{PsyC}=$ Psychological Characteristic, EC= Entrepreneur Competency, $\mathrm{FL}=$ Financial Literacy.

\section{Result and Discussion}

Research model is evaluated in two stages, respectively, evaluation of measurement model and evaluation of structural model. The evaluation of research model is conducted using PLS-SEM with computer application of WarpPLS version 6.0. Two algorithm methods are used in this research. Outer model is examined with PLS at Regression Mode, while inner model is checked with warp2 (non-linear). Both methods are chosen because they produce p-value with the best significance level (Sholihin \& Ratmono, 2013). Method of resampling is stable method, which represents the default method at the application of WarpPLS 6.0.

\section{Evaluation of Measurement Model}

Evaluation of measurement model is conducted to assess reliability and validity values of indicators that shape latent variables. Due to the concepts that underline research model, all research variables are measured with reflective indicators. Latan and Ghozali (2016) said that reliability and validity of outer model are measured with reflective indicators, and the measurement involves some conditions as follows:

1. Indicators are considered as achieving indicator reliability if they have factor loading value $>0.6$.

2. Internal consistency's reliability is achieved if composite reliability value of the variables is $>0.7$.

3. Convergent validity is achieved only if the rate of Average Variance Extracted (AVE) of the variables is $>0.5$. 
4. Discriminant validity is fulfilled if the rate of Square-Root AVE is $>$ the rate of correlations across variables.

Factor loading values of indicators that explain research variables are presented in table 2.

Table 2 Factor Loading Value of the Indicators that Explain Research Variables

\begin{tabular}{|c|c|c|}
\hline Variable & Indicator & Factor Loading \\
\hline Personal & Age & 0.803 \\
\hline \multirow[t]{3}{*}{ Characteristic (PerC) } & Education & 0.584 \\
\hline & Experience & 0.775 \\
\hline & Cosmopolite & 0.256 \\
\hline Psychological & Hard working & 0.717 \\
\hline \multirow[t]{9}{*}{ Characteristic (PsyC) } & Self-confident & 0.716 \\
\hline & Discipline & 0.700 \\
\hline & Dare to take the risk & 0.618 \\
\hline & Innovative & 0.700 \\
\hline & Self-reliant and responsible & 0.800 \\
\hline & Having future vision & 0.765 \\
\hline & Thinking out of the box & 0.374 \\
\hline & Capable to capture opportunity & 0.630 \\
\hline & Flexible and open-minded & 0.804 \\
\hline \multirow{10}{*}{$\begin{array}{l}\text { Entrepreneur } \\
\text { Competency (EC) }\end{array}$} & Managerial competency & 0.732 \\
\hline & Conceptual competency & 0.716 \\
\hline & Capable of making decisions & 0.700 \\
\hline & Capable of setting times & 0.403 \\
\hline & Managerial and organizational experiences & 0.503 \\
\hline & Dislike the routines (or traditions) & 0.376 \\
\hline & Internal control & 0.814 \\
\hline & Capable to invest the resources & 0.541 \\
\hline & Efficient self-management & 0.700 \\
\hline & Social competency & 0.548 \\
\hline \multirow{4}{*}{$\begin{array}{l}\text { Financial Literacy } \\
(\mathrm{FL})\end{array}$} & Basic knowledge about financial management & 0.798 \\
\hline & Credit management & 0.006 \\
\hline & Savings \& investment & 0.700 \\
\hline & Risk management & 0.615 \\
\hline \multirow{5}{*}{$\begin{array}{l}\text { Business } \\
\text { Performance }(P)\end{array}$} & Earnings & 0.821 \\
\hline & Sale rate & 0.710 \\
\hline & Fixed cost lowering & 0.034 \\
\hline & $\begin{array}{l}\text { Be anticipative in production on the } \\
\text { increasing demand }\end{array}$ & 0.700 \\
\hline & Surety of punctuality for customers & 0.504 \\
\hline
\end{tabular}

Source: Primary data are processed (2018)

Some indicators have factor loading value below 0.6. Based on the rule of thumb in measuring reliability and validity, indicators with factor loading value less than 0.6 are not included in (or eliminated from) the measurement of research variables. Factor loading value of indicators, and composite reliability and AVE of the variables are shown in Table 3. 
The Role of Entrepreneur Characteristic and Financial Literacy in Developing Business Success

Table 3 Factor Loading, Composite Reliability and Average Variance Extract

\begin{tabular}{|c|c|c|c|c|}
\hline Variable & Indicator & $\begin{array}{l}\text { Factor } \\
\text { Loading }\end{array}$ & $\begin{array}{l}\text { Composite } \\
\text { Reliability }\end{array}$ & AVE \\
\hline \multirow{2}{*}{$\begin{array}{l}\text { Personal } \\
\text { Characteristic }\end{array}$} & Age & 0.803 & 0.851 & 0.741 \\
\hline & Experience & 0.775 & & \\
\hline \multirow{7}{*}{$\begin{array}{l}\text { Psychological } \\
\text { Characteristic }\end{array}$} & Hard working & 0.717 & 0.903 & 0.573 \\
\hline & Self-confident & 0.716 & & \\
\hline & Discipline & 0.651 & & \\
\hline & Innovative & 0.679 & & \\
\hline & $\begin{array}{l}\text { Self-reliant and } \\
\text { responsible }\end{array}$ & 0.8 & & \\
\hline & Having future vision & 0.765 & & \\
\hline & $\begin{array}{l}\text { Flexible and open- } \\
\text { minded }\end{array}$ & 0.804 & & \\
\hline \multirow[t]{5}{*}{$\begin{array}{l}\text { Entrepreneur } \\
\text { Competency }\end{array}$} & $\begin{array}{l}\text { Managerial } \\
\text { competency }\end{array}$ & 0.732 & 0.852 & 0.591 \\
\hline & $\begin{array}{l}\text { Conceptual } \\
\text { competency }\end{array}$ & 0.716 & & \\
\hline & $\begin{array}{l}\text { Capable of making } \\
\text { decisions }\end{array}$ & 0.641 & & \\
\hline & Internal control & 0.814 & & \\
\hline & $\begin{array}{l}\text { Efficient self- } \\
\text { management }\end{array}$ & 0.686 & & \\
\hline \multirow[t]{2}{*}{$\begin{array}{l}\text { Financial } \\
\text { Literacy }\end{array}$} & $\begin{array}{l}\text { Basic knowledge } \\
\text { about financial } \\
\text { management }\end{array}$ & 0.798 & 0.794 & 0.658 \\
\hline & $\begin{array}{l}\text { Savings \& investment } \\
\text { management }\end{array}$ & 0.679 & & \\
\hline \multirow{3}{*}{$\begin{array}{l}\text { Business } \\
\text { Performance }\end{array}$} & Earnings & 0.821 & 0.813 & 0.594 \\
\hline & Sale rate & 0.71 & & \\
\hline & $\begin{array}{l}\text { Be anticipative in } \\
\text { production on the } \\
\text { increasing demand }\end{array}$ & 0.697 & & \\
\hline
\end{tabular}

Source: Primary data are processed (2018)

As shown by the table above, all indicators that explain variables of Personal Characteristic, Psychological Characteristic, Entrepreneur Competency, Financial Literacy, and Business Performance, are considered as valid because all have factor loading value above 0.6. Therefore, all indicators in this table are those that achieve indicator reliability. Moreover, AVE rates of the variables are $>0.5$, which thus put the variables in very good category because they fulfill the condition of convergent validity. Composite Reliability values of the variables are $>0.7$, which lay the variables in very good category because they fulfill the condition of internal consistency's reliability.

The rate of Square-Root AVE is compared with the rate of correlations across the variables/constructs. The result of this comparison is indicated in Table 4. 
The Role of Entrepreneur Characteristic and Financial Literacy in Developing Business Success

Table 4. Square-Root AVE and Correlations across the Constructs

\begin{tabular}{llccccc}
\hline Variable / Construct & $\begin{array}{l}\text { Square- } \\
\text { Root AVE }\end{array}$ & PerC & PsyC & EC & FL & P \\
\hline $\begin{array}{l}\text { Personal Characteristic } \\
\text { (PerC) }\end{array}$ & 0.861 & 1 & 0.25 & 0.132 & 0.007 & 0.12 \\
$\begin{array}{l}\text { Psychological } \\
\text { Characteristic (PsyC) }\end{array}$ & 0.757 & 0.25 & 1 & 0.611 & 0.327 & 0.387 \\
$\begin{array}{l}\text { Entrepreneur } \\
\text { Competency }\end{array}$ & 0.769 & 0.132 & 0.611 & 1 & 0.285 & 0.18 \\
$\begin{array}{l}\text { (EC) } \\
\text { Financial Literacy (FL) }\end{array}$ & 0.811 & 0.007 & 0.327 & 0.285 & 1 & 0.409 \\
\begin{tabular}{l} 
Business Performance (P) \\
\hline
\end{tabular} & 0.771 & 0.12 & 0.387 & 0.18 & 0.409 & 1 \\
\hline
\end{tabular}

Source: Primary data are processed (2018)

Square-Root AVE of each variable is higher than the rate of correlations across variables, and therefore, the variables show good discriminant validity.

Evaluation of Structural Model

Evaluation of structural model (inner model) is conducted to predict relationship across variables by examining how much variance should be explained in order to acknowledge the significance of P-value (Latan \& Ghozali, 2016). This evaluation should facilitate the author in conducting hypothesis test.

Before evaluating the relationship across variables, goodness-of-fit of research must be evaluated first. The output of this evaluation is shown in Table 5.

Table 5 Goodness-of-Fit of Structural Model

\begin{tabular}{|c|c|c|}
\hline Criteria & Parameter & Rule of Thumb \\
\hline Average path coefficient (APC) & $0.247 / P<0.001$ & Acceptable if $P<0.05$ \\
\hline Average R-squared (ARS) & $0.350 / P<0.001$ & Acceptable if $P<0.05$ \\
\hline Average adjusted R-squared (AARS) & $0.323 / P<0.001$ & Acceptable if $P<0.05$ \\
\hline Average block VIF (AVIF) & 1.381 & $\begin{array}{l}\text { Acceptable if }<=5 \text {, Ideally } \\
<=3.3\end{array}$ \\
\hline Average full collinearity VIF (AFVIF) & 1.452 & $\begin{array}{l}\text { Acceptable if }<=5 \text {, Ideally } \\
<=3.3\end{array}$ \\
\hline Tenenhaus GoF (GoF) & 0.470 & $\begin{array}{l}\text { Small if }>=0.1 \text {, Medium if } \\
>=0.25, \text { Large if }>=0.36\end{array}$ \\
\hline Sympson's paradox ratio (SPR) & 1.000 & $\begin{array}{l}\text { Acceptable if }>=0.7 \\
\text { Ideally }=1\end{array}$ \\
\hline R-squared contribution ratio (RSCR) & 1 & $\begin{array}{l}\text { Acceptable if }>=0.9 \\
\text { Ideally }=1\end{array}$ \\
\hline Statistical suppression ratio (SSR) & 1 & Acceptable if $>=0.7$ \\
\hline $\begin{array}{l}\text { Non-linear bivariate causality } \\
\text { direction ratio (NLBCDR) }\end{array}$ & 0.875 & Acceptable if $>=0.7$ \\
\hline
\end{tabular}

Source: Primary data are processed (2018) 
Based on the outputs of the table above, it can be said that research model has good fit because P-values for APC, ARS, and AAR are $<0.05$, precisely APC $=0.247$, ARS $=0.350$, and AARS $=0.323$. The rates of both AVIF and AFVIF are $<3.3$, and thus, there is no multicollinearity problem across indicators and across exogenous variables. Goodness-offit (GoF) has rate of $0.470>0.36$, which signifies that research model has very good fit. The parameters of SPR, RSCR, and SSR are equaled to 1 , and NLBCDR has parameter of 0.875 , which based on these results, it is said that there is no causality problem in research model (Latan \& Ghozali, 2016).

The estimated relationship across variables and the rate of variance are displayed in table 6. In addition, the estimation of relationship across variables and the rate of variance are illustrated in Figure 1.

Table 6 The Estimated Relationship across Variables

\begin{tabular}{lllll}
\hline Description Path & Path Coefficient & P-value & $\mathrm{R}^{2}$ & $\mathrm{Q}^{2}$ \\
\hline $\begin{array}{l}\text { Personal Characteristic } \rightarrow \\
\text { Business Performance }\end{array}$ & 0.181 & $<0.01$ & 0.350 & 0.299 \\
$\begin{array}{l}\text { Psychological Characteristic } \\
\rightarrow \text { Business Performance }\end{array}$ & 0.371 & $<0.01$ & & \\
$\begin{array}{l}\text { Entrepreneur Competency } \\
\rightarrow \text { Business Performance }\end{array}$ & 0.136 & 0.039 & & \\
$\begin{array}{l}\text { Financial Literacy } \\
\rightarrow \text { Business Performance }\end{array}$ & 0.3 & $<0.01$ & & \\
\hline
\end{tabular}

Source: Primary data are processed (2018)

In addition, the estimation of relationship across variables and the rate of variance are illustrated in Figure 1.

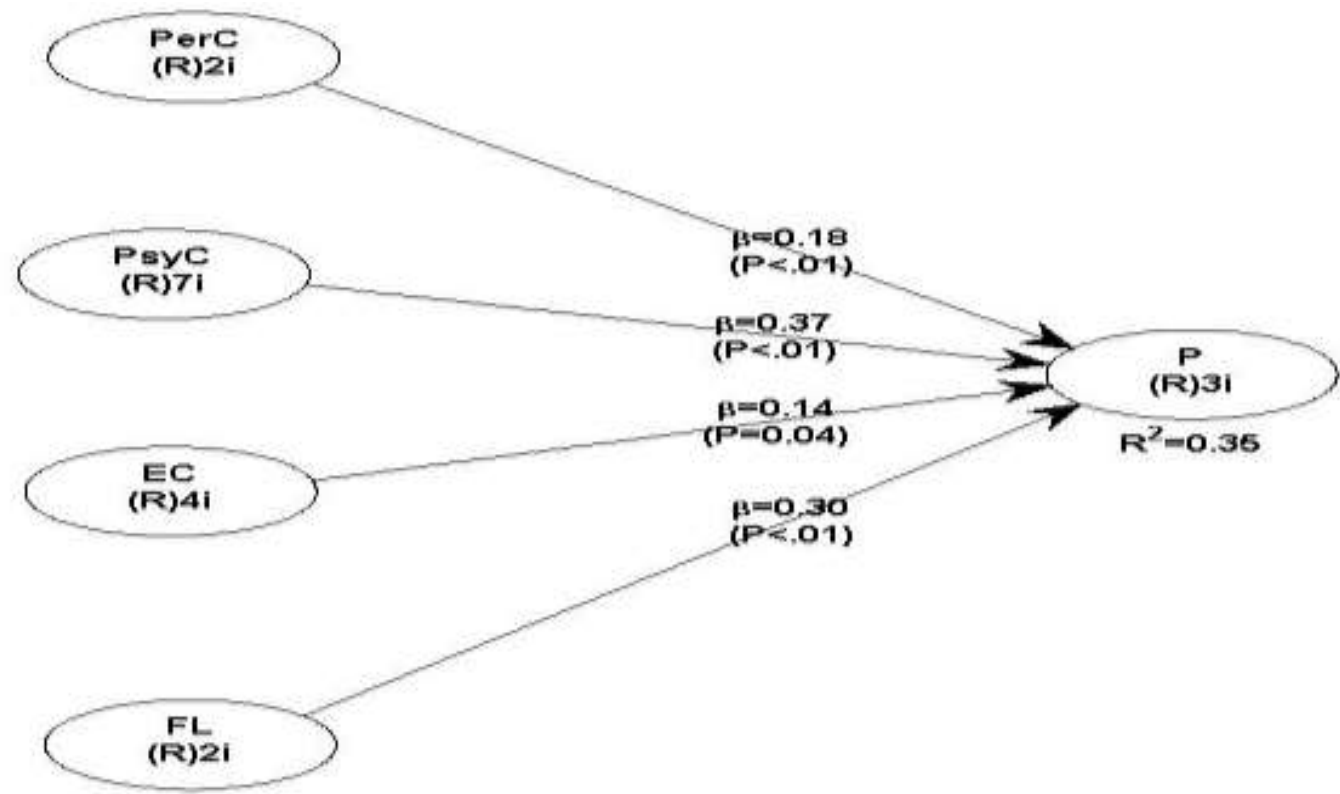

Figure 1 Path Diagram of the Significance Level of The Effect Across Variables 


\section{Utomo, Cahyaningrum, \& Kaujan \\ The Role of Entrepreneur Characteristic and Financial Literacy in Developing Business Success}

As indicated in Table 6, R-squared $\left(R^{2}\right)$ for the variance that affects Business Performance is 0.35 . Pursuant to this result, it can be said that the effect of the variances of Personal Characteristic, Psychological Characteristic, Entrepreneur Competency, and Financial Literacy, on the variance of Business Performance, is valued at $35 \%$, while the remaining $65 \%$ are affected by other variable out of research model. The rate of $R$-squared $\left(R^{2}\right)$ that affects Business Performance is included into moderate category $\left(R^{2}>0.25\right)$. Moreover, the rate of Q-Squared for Business Performance is $0.299(>0)$, which from this, it can be said that research model has predictive relevancy (Latan \& Ghozali, 2016).

By taking into account the outputs of Table 6 and path description in Figure 1, some preliminary indications can be explained as follows. Personal Characteristic has positive and significant effect on Business Performance, and this relationship has path coefficient value of 0.181 and P-value of $<0.01$. It supports Hypothesis 1 , and thus, this hypothesis is accepted. This result corresponds with Upper Echelon Theory because the theory says that organization and anything inside it are the reflection of the characteristic of topmanagement (Hambrick \& Mason, 1984). These findings are in line with previous studies conducted by Sambu and Kihara (2015) and Mothibi (2015) who found that personal characteristic has positive impact on business performance. If entrepreneurs have better personal characteristic, it must improve their business performance. Entrepreneurs who are in productive age and have more entrepreneurship experiences should be more motivated to manage their business more efficiently to attain better business performance.

Psychological characteristic has positive and significant effect on business performance. This relationship has path coefficient value of 0.371 and $P$-value of $<0.01$. It supports Hypothesis 2 and thus, this hypothesis is accepted. Previous studies that corroborate this finding include Sari et al. (2016), Abdulwahab and Al-Damen (2015) and Isaga (2017). In general, these studies assert that personal characteristic of entrepreneurs has significant effect on performance of Small-and-Medium Enterprises. Psychological characteristic has positive effect on business performance, and this positive sign can be described as that better psychological characteristic must motivate entrepreneurs to improve business performance. The current research confirms that psychological characteristic (represented by indicators of hard working, self-confident, discipline, innovative, selfreliant and responsible, having future vision, and flexible and open-minded) is determinant to whether entrepreneurs are successful or not in developing their business. This finding is contributive to Upper Echelon Theory, which explains that there is a relationship between entrepreneur characteristic and business performance (Hambrick \& Mason, 1984).

Moreover, the outputs of Table 6 and the description in Figure 1 also display that entrepreneur competency has positive and significant effect on business performance at path coefficient value of 0.136 and P-value of 0.04 . It supports Hypothesis 3 and thus, this hypothesis is accepted. This result gives confirmation to the previous studies conducted by Camuffo, Gerli, and Gubitta (2012), Barazandeh, Parvizian, Alizadeh, and Khosravi (2015) and Pamela, Pambudy, and Winandi (2016). These studies, in general, found that entrepreneur competency has positive effect on business performance. In other words, if 


\section{Utomo, Cahyaningrum, \& Kaujan \\ The Role of Entrepreneur Characteristic and Financial Literacy in Developing Business Success}

entrepreneurs are more competent in their business, they might be successful in improving their business performance. The current research proves that entrepreneurs with good managerial and conceptual competencies are those who can map their business properly, and these competencies have positive impact on performance. Making appropriate decisions, good internal control, and efficient self-management are the determinant factors to the successful business performance.

Other result shows that financial literacy has positive and significant effect on business performance. This relationship is given with path coefficient value of 0.3 and P-value of $<0.01$. Hypothesis 4 is supported, and that is why this hypothesis is accepted. This result justifies Resource-Based View Theory where this theory says that if firms are able to manage the existing resources into valuable, rare, inimitable and unsubstitutable products, then such firms will be able to improve their performance and get sustainable competitive advantage (Barney, 1991). This finding is also in accord with previous studies conducted by Dahmen and Rodríguez (2014), Aribawa (2016) and Eniola and Entebang (2016). In general, these studies found that financial literacy has positive impact on business performance. Also, it can be said that high financial literacy, especially concerning with financial management, allows entrepreneurs to have better access to financial sources (as resources), which then manage these resources to improve business performance. Entrepreneurs who are able to manage savings \& investment efficiently should then be supportive to effort to attain high business performance.

\section{Conclusion}

The current research attempts to answer the question of whether entrepreneurs' characteristic and competency, and also financial literacy are factors that determine successful performance of Small-and-Medium Enterprises in Tarakan City. Four hypotheses are proposed to answer this question. Hypothesis 1 has been tested, and the result shows that better personal characteristic improves business performance. Result of test on Hypothesis 2 shows that better psychological characteristic also improves business performance. Hypothesis test on Hypothesis 3 gives a result that entrepreneurs who are more competent in entrepreneurship are finding themself in easier way to improve business performance. The testing on Hypothesis 4 has given a result that high financial literacy has positive effect on business performance. High financial literacy, which is indicated by financial management and savings \& investment management, is indeed the valuable, rare and inimitable resource.

Moreover, there are more explanations about how to improve business performance. Psychological characteristic has the biggest positive effect on business performance. Its path has the highest path coefficient value, which based on it, then can be said that psychological characteristic plays the most important role to the improvement of business performance. Financial literacy occupies the best second rank in improving business performance, and therefore, financial literacy is very important to entrepreneurs. 
The Role of Entrepreneur Characteristic and Financial Literacy in Developing Business Success

\section{Suggestions}

Practical implication that can be suggested by the current research is that any entrepreneurs must have psychological characteristic of hard working, self-confident, discipline, innovative, self-reliant and responsible, having future vision, and flexible and open-minded. Entrepreneurs must understand and improve their financial literacy to improve their business performance. Financial literacy can be acquired from mass media or from specific training that educate entrepreneurs with knowledge about financial affairs.

This study has limitations, namely, the sample used is SMEs with mixed business sectors. The sample has not been specifically determined based on sectors such as industry, trade, and services. Though each sector has a different character so it can produce different conclusions as well. Future research can improve by using samples specifically based on the business sector.

\section{References}

Abdulwahab, M. H., \& Al-Damen, R. A. (2015). The Impact of Entrepreneurs' Characteristics on Small Business Success at Medical Instruments Supplies Organizations in Jordan. International Journal of Business and Social Science, 6(8), 164-175. Retrieved from http://ijbssnet.com/journals/Vol 6 No 8 August 2015/17.pdf

Abood, N., \& Aboyasin, N. A. (2014). Impact of the Entrepreneurial Attributes on Business Performance in a Sample of Jordanian Institutions. International Journal of Professional Management, 9(1), 1-18.

Adomako, S., \& Dans, A. (2014). Financial Literacy and Firm performance: The moderating role of financial capital availability and resource flexibility. International Journal of Management \& Organizational Studies, 3(4). Retrieved from https://www.dora.dmu.ac.uk/handle/2086/13895

Arasti, Z., Zandi, F., \& Bahmani, N. (2014). Business failure factors in Iranian SMEs: Do successful and unsuccessful entrepreneurs have different viewpoints? Journal of Global Entrepreneurship Research, 4(10), 1-14. https://doi.org/10.1186/s40497-014-0010-7

Ariani, \& Utomo, M. N. (2017). Kajian Strategi Pengembangan Usaha Mikro Kecil dan Menengah (UMKM) Di Kota Tarakan. Jurnal Organisasi dan Manajemen, 13(2), 99-118. https://doi.org/10.33830/jom.v13i2.55.2017

Aribawa, D. (2016). Pengaruh Literasi Keuangan Terhadap Kinerja dan Keberlangsungan UMKM di Jawa Tengah. Siasat Bisnis, 20(1), 1-13. https://doi.org/10.20885/isb.vol20.iss1.art1

Barazandeh, M., Parvizian, K., Alizadeh, M., \& Khosravi, S. (2015). Investigating the effect of entrepreneurial competencies on business performance among early stage entrepreneurs Global Entrepreneurship Monitor (GEM 2010 survey data). Journal of Global Entrepreneurship Research, 5(18), 1-12. https://doi.org/10.1186/s40497-015-0037$\underline{4}$

Barney, J. (1991). Firm resources and sustained competitive advantage. Journal of Management, 17(1), 99-120. https://doi.org/10.1177/014920639101700108

Basu, S. (2005). White Paper: Financial literacy and the life cycle. Paper presented at the White House Conference on Aging. 
Camuffo, A., Gerli, F., \& Gubitta, P. (2012). Competencies matter: modeling effective entrepreneurship in northeast of Italy small firms. Cross Cultural Management, 19(1), 4866. Retrieved from https://www.researchgate.net/publication/235319381_Competencies matter_Modeli ng effective entrepreneurship in northeast of Italy small firms

Chell, E. (2008). The Entrepreneurial Personality. London: Routledge.

Chen, H., \& Volpe, R. P. (1998). An Analysis of Personal Financial Literacy Among College Students. Financial Services Review, 7(2), 107-128. https://doi.org/10.1016/s1057$\underline{0810(99) 80006-7}$

Dahmen, P., \& Rodríguez, E. (2014). Financial Literacy and the Success of Small Businesses: an Observation from a Small Business Development Center. Numeracy, 7(1), 1-12. https://doi.org/10.5038/1936-4660.7.1.3

Davis, J. A., Marino, L. D., \& Vecchiarini, M. (2013). Exploring the Relationship between Nursing Home Financial Performance and Management Entrepreneurial Attributes. Advances in Health Care Management, 14, 147-165. https://doi.org/10.1108/s1474$\underline{8231(2013) 00000140011}$

Eniola, A. A., \& Entebang, H. (2016). Financial literacy and SME firm performance. International Journal of Research Studies in Management, 5(1), 31-43. https://doi.org/10.5861/ijrsm.2015.1304

Garman, E. T., \& Forgue, R. E. (2002). Personal finance. Lexington: Lexington Volunteer Recording Unit.

Hambrick, D. C., \& Mason, P. A. (1984). Upper Echelons: The Organization as a Reflection of Its Top Managers. The Academy of Management Review, 9(2), 193-206. https://doi.org/10.5465/amr.1984.4277628

Hilgert, M. A., \& Hogarth, J. M. (2003). Household Financial Management: The Connection Between Knowledge and Behaviour. Federal Reserve Bulletin, 89(7), 309-322. Retrieved from https://econpapers.repec.org/article/fipfedgrb/y 3a2003 3ai 3ajul 3ap 3a309322 3an 3av.89no.7.htm

Hornaday, J. A. (1982). Research about living entrepreneurs. Encyclopedia of entrepreneurship. Englewood Cliffs, 20-34.

Isaga, N. (2017). The relationship of personality to cognitive characteristics and SME performance in Tanzania. Journal of Small Business and Enterprise Development. 25(4). 667686. https://doi.org/10.1108/jsbed-02-2017-0067

Karayiannis, A. (2003). Entrepreneurial Functions and Characteristics in a Proto-Capitalist Economy the Xenophonian Entrepreneur. Wirtschaftspolitische Blatte, 50, 553-563. Retrieved from http://citeseerx.ist.psu.edu/viewdoc/download?doi=10.1.1.466.5850\&rep=rep1\&typ $\underline{\mathrm{e}=\mathrm{pdf}}$

Latan, H., \& Ghozali, I. (2016). Partial Least Square Konsep, Metode dan Aplikasi Menggunakan WarpPLS 5.0. Semarang: Badan Penerbit Universitas Diponegoro.

LEI. (2018). Ini Kontribusi Koperasi dan UMKM Terbadap PDB Nasional 2017. Legal Era Indonesia.

Lusardi, A., \& Mitchell, O. S. (2007). Financial Literacy and Retirement Preparedness: Evidence and Implications for Financial Education. Lusardi, A, and Mitchell, O.S (2007b). Business Economics 42(1),, 42(1), 35-44. https://doi.org/10.2145/20070104

Mothibi, G. (2015). The Effects of Entrepreneurial and Firm Characteristics on Performance Of Small and Medium Enterprises in Pretoria. International Journal of Economics, Commerce and Management, III(3), 1-8. Retrieved from https://pdfs.semanticscholar.org/b3ee/bec736857294f1 fc6cd06b752455ef43cea9.pdf 
OJK. (2016). Survei Nasional Literasi Dan Inklusi Keuangan 2016. Retrieved from Jakarta: Pamela, Pambudy, R., \& Winandi, R. (2016). Kompetensi Kewirausahaan Dengan Keberhasilan Usaha Peternak Sapi Perah Pujon, Malang. Jurnal Agribisnis Indonesia, 4(1), 57-66. https://doi.org/10.29244/jai.2016.4.1.57-66

Plakalovic, N. (2015). Financial Literacy of Smes Managers. Paper presented at the Management, Knowledge and Learning Joint International Conference 2015, Italy. Retrieved from http://www.toknowpress.net/ISBN/978-961-6914-130/papers/ML15-086.pdf

Sambu, F. K., \& Kihara, N. P. (2015). Entrepreneurial Characteristics and Performance of Learning Institutions an Empirical Evidence from Kenya. International Journal of Economics, Commerce and Management, 3(8), 140-155.

Sari, N. M. W., Suwarsinah, H. K., \& Baga, L. M. (2016). Pengaruh Karakteristik Kewirausahaan terhadap Kinerja Usaha Mikro, Kecil dan Menengah(UMKM) Gula Aren di Kabupaten Lombok Barat. Jurnal Penyuluban, 12(1), 51-60. https://doi.org/10.25015/penyuluhan.v12i1.11320

Sholihin, M., \& Ratmono, D. (2013). Analisis SEM-PLS dengan Warp PLS 3.0 untuk. Hubungan Nonlinier dalam Penelitian Sosial dan Bisnis. Yogyakarta: Penerbit ANDI.

Singh, S., \& Pathak, R. D. (2013). Interplay between entrepreneurial characteristics, organisational structure, corporate culture and SME performance: empirical results from Fiji Islands. Int. J. Entrepreneurship and Small Business, 18(2), 229-245. https://doi.org/10.1504/ijesb.2013.052076

Sudarno. (2011). Kontribusi Usaha Mikro, Kecil dan Menengah (UMKM) Dalam Penyerapan Tenaga Kerja di Depok. Jurnal Ekonomi dan Bisnis, 10(2), 139-146. Retrieved from https://media.neliti.com/media/publications/13447-ID-kontribusiusaha-mikro-kecil-dan-menengahumkm-dalam-penyerapan-tenaga-kerja-di-d.pdf Sukidjo. (2005). Peran Kewirausahaan dalam Mengatasi Pengangguran di Indonesia. Jurnal Ekonomia, 1(1), 17-28. 